\title{
The Impact of Applying the Theory of Constraints on the Competitive Advantage: Evidence from Jordan
}

Ibtisam Salem Almasaeid

To Link this Article: http://dx.doi.org/10.6007/IJARAFMS/v11-i4/11808 DOI:10.6007/IJARAFMS /v11-i4/11808

Received: 17 October 2021, Revised: 20 November 2021, Accepted: 29 November 2021

Published Online: 11 December 2021

In-Text Citation: (Almasaeid, 2021)

To Cite this Article: Almasaeid, I. S. (2021). The Impact of Applying the Theory of Constraints on the Competitive Advantage: Evidence from Jordan. International Journal of Academic Research in Accounting Finance and Management Sciences, 11(4), 71-81.

\section{Copyright: @ 2021 The Author(s)}

Published by Human Resource Management Academic Research Society (www.hrmars.com)

This article is published under the Creative Commons Attribution (CC BY 4.0) license. Anyone may reproduce, distribute, translate and create derivative works of this article (for both commercial and non-commercial purposes), subject to full attribution to the original publication and authors. The full terms of this license may be seen at: http://creativecommons.org/licences/by/4.0/legalcode

Vol. 11, No. 4, 2021, Pg. 71 - 81

Full Terms \& Conditions of access and use can be found at http://hrmars.com/index.php/pages/detail/publication-ethics 


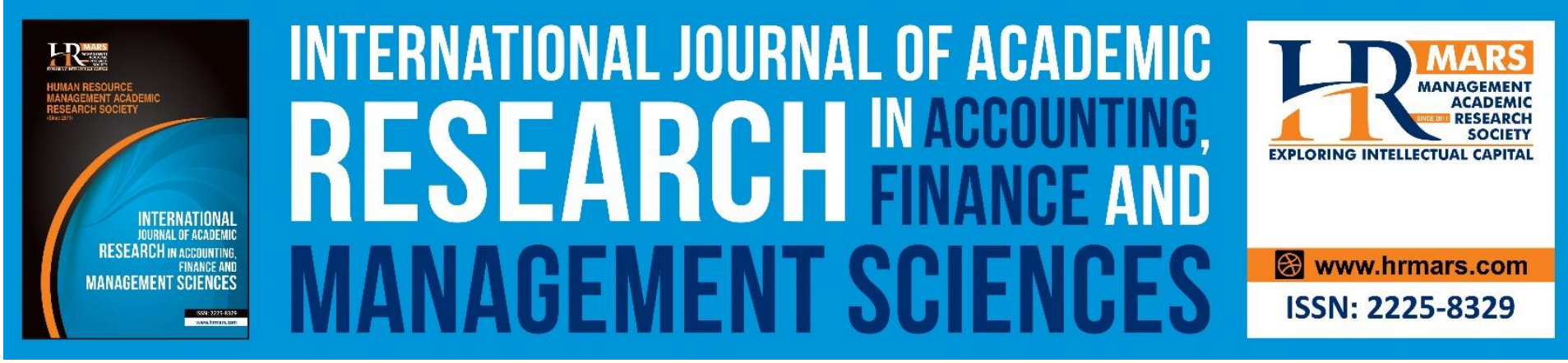

\title{
The Impact of Applying the Theory of Constraints on the Competitive Advantage: Evidence from Jordan
}

\author{
Ibtisam Salem Almasaeid \\ Assistant manager in internal control department At Al Albayt university \\ Email: almasaeidibtisam@gmail.com
}

\begin{abstract}
The theory of constraints is a methodology for determining the constraint that stands in the way of the company to achieve its goals. The theory is based on the continuous improvement of the company's operations, to improve its performance and create a competitive advantage for it. thus, The theory of constraints is one of the important subject for literature over the past years to investigate. Therefore, this paper aimed to investigate the impact of applying the theory of constraints on the competitive advantage for Industrial companies in Jordan. The descriptive statistical method was used, the study population consisted of employees in the Industrial companies in Al Mafraq Industrial Estate, and (60) questionnaires were distributed to the sample members, which consisted of (managers, engineers, accountants, supervisors, and technicians), and the number of Questionnaires retrieved and valid for analysis (50) questionnaires. The study showed a statistically significant impact of applying the theory of constraints on the competitive advantage for Industrial companies in Jordan. The study recommend it is necessary for industrial companies to search for the best ways and methods that help reduce constraints, reduce waste of resources, and continuous improvement in production processes, in order to maintain their competitive advantage, and also recommended studying the impact of applying the theory of constraints on other variables or in other environments.
\end{abstract}

Keywords: Theory of Constraints, Competitive Advantage, Industrial Companies, Jordan, Al Mafraq Industrial Estate.

\section{Introduction}

Scientific progress, rapid technological developments, local and global competition witnessed by industrial companies, the difficulty of meeting the needs of customers, and the desire of these companies to grow, succeed, survive and continue their operations and activities, that's require from them to respond quickly for any changes in the internal and external environment, and to make radical changes in its operations, and changing their systems and strategies in order to achieve its survival and growth, to improve the quality of its products, meet the needs of their customers, reduce its costs, and improve their performance (Orue, et al., 2021). The management accounting information system can help to respond to changes 
MANAGEMENT SCIENCES

Vol. 11, No. 3, 2021, E-ISSN: 2225-8329 @ 2021 HRMARS

in the business environment, and the theory of constraints and related concepts have come to contribute to the development of management accounting information systems in a manner that is appropriate for adapts to changes in the environment.

The constraints exist in all areas, as it can be to say that it is not possible to imagine the existence of any activity that is free of constraints, whether related to the scarcity of resources, or the locations of bottlenecks (constraints), and the theory of constraints came to focus attention on managing those constraints to improve company operations (Balakrishnan, Cheng \& Trietsch, 2008). The theory of constraints is one of the philosophies related to cost management and focus on continuous improvement for operational processes to improved organizational performance (Inman, Sale \& Green, 2009). this theory focus on maximizing profitability by emphasizing the need for efficient and effective use of resources that are restricted or control the production flow, and then in the overall productivity of the facility, focusing primarily on the quality of those products, with the aim of increasing the operating income of the company, and improving the company's competitive advantage through its five dimensions, cost, quality, delivery flexibility, creativity, and time (Skinner, 2007; Da silveria, 2005). This study has studied the impact of applying the theory of constraints on the competitive advantage in manufacturing companies in Jordan.

\section{Study Problem}

The local and global economy is witnessing strong competition between industrial companies, which requires companies to maintain their survival and continuity, by strengthening its competitive position in the market, this matter made the companies to look for successful methods to continue and survive in the competitive markets, and from these methods used by companies are the theory of constraints, which helps in managing bottlenecks and constraints, to focus on developing and improving production processes, and reducing the cost of products to maintain quality, In order to increase profitability and overcome competition, which dominates the market, and from the above the researcher conclude that the problem of the study is to answer the following question:

What is the impact of applying the theory of constraints on the competitive advantage for industrial companies in Jordan?

\section{Study Objectives}

This study aimed to:

- Define the theory of constraints concept, and its objectives, and the importance of its application in industrial companies in Jordan.

- Define the competitive advantage concept, and its dimensions, and its importance for industrial companies in Jordan.

- To investigate the impact of applying the theory of constraints on the competitive advantage for industrial companies in Jordan.

\section{Study Hypothesis}

To achieve the objectives of this study, the following main hypothesis was formulated:

There is no statistically significant impact of applying the theory of constraints on the competitive advantage. 
MANAGEMENT SCIENCES

Vol. 11 , No. 3, 2021, E-ISSN: 2225-8329 @ 2021 HRMARS

\section{Theoretical Framework}

\section{Theory of Constraints}

With the increase in global competition witnessed by industrial companies, and the increase in pressures on the management of these companies to exploit their economic resources efficiently and effectively, this led companies to apply effective administrative methods like theory of constraints, to help in dealing with the pressures that companies are exposed to and contribute to improving and developing their operations (Tsou, 2013). The main goal of the majority of companies is to improve their performance, to achieve maximum profits in light of their available resources, and with the bottlenecks and constraints facing companies, whether they are from scarcity of resources, industrial environment factors or competition factors, this made companies to adopt systems and theories to ensure that these constraints and bottlenecks are removed or reduced it, which helps in improving the performance of companies and achieving maximum profits through the effective management for these constraints to reduce costs, develop products, and improve their quality (Al-Maadidi \& AlHadidi, 2008).

The theory of constraints is based on the assumption that there is at least one constraint in any system, and this theory is used for the purpose of determining the internal and external determinants and constraints that affect the company's system and limit its achievement of the objectives required of it, and to develop appropriate options to deal with these determinants and constraints, to maximize outputs by determining the mix The optimum productivity in light of the available resources, to contribute to increasing the contribution return for the product during a certain period of time, and thus increase the profitability of the company (Al-Zamili, 2014). Constraint is defined as any element or factor that limits the work of the system from doing more of what it was designed to achieve (Liu, Shen \& Zhang, 2021), and also a constraint is anything that limits the ability of the system to achieve its goals, it is taken as the basis for managing and improving the system(Goldratt \& Cox, 2004), and the presence of this constraint stimulates the economic unit to Making continuous improvements, through the continuous search for innovative and successful solutions (AlZamili, 2014), and the theory of constraints is a management method that enables the company to increase its operating income, if it effectively manages those constraints facing its operations (Atkinson et.al., 2012).

\section{Objectives of the Theory of Constraints}

The theory of constraints aims to make money now and in the future, by managing constraints effectively, and this theory recognizes that the performance of any company (system) is limited because its constraints, and operationally every system contains at least one constraint that determines productivity (Simsit, Gunay \& Vayvay, 2014). The theory of constraints develops an approach New to support the goal of continuous improvement, and each company or system is represented by interconnected chains, and each chain of them has a weak link that may limit the performance of the chain as a whole, and the weakest link is the system constraint, which is the key to improving the overall performance of the company (Hansen \& Mowen, 2006). The theory of constraints (TOC) describes ways to maximize operating income when certain bottlenecks are encountered, a bottleneck is defined as any condition that impedes or restricts the effective flow of operations, and there three measures need to be applied (Atkinson et.al, 2012):

Output contribution: equal to sales value minus direct material costs. 
- Investment: It is equal to the value of inventory costs (direct costs, cost of work in process, and costs of finished goods).

- Operational costs: They are equal to all other operational costs, except for direct materials, and occur to achieve the contribution of outputs such as (depreciation costs, salaries and rent).

The theory of constraints (TOC) aims to increase the contribution of output, while reducing investments and operational costs, and focuses on improving productivity in the short term, assuming that operating costs are fixed in the short term, and the theory of constraints (TOC) focuses on managing constraints and bottlenecks through the following steps (horngren et. al., 2015):

1- Knowing that the bottleneck (constraints) affects the productivity margin of the company as a whole.

2- Determining the constraints that affect the company's operations.

3- Determining how to exploit the constraints (bottlenecks) by using resources that do not have constraints or bottlenecks to support the resources that have bottlenecks, to achieve maximum effectiveness and productivity of the resources that have restrictions, and to improve the company's operations.

4- Taking measures to increase the efficiency and capacity of the resources that have constraints, so that the margin of productivity exceeds the additional costs of increasing the efficiency and capacity of the resources.

\section{The Importance of Applying the Theory of Constraints}

The theory of constraints is a key to achieving continuous growth and stability for any company, by finding a way to focus its scarce resources on only that part that currently limits or impedes further improvements, because improving the exploitation or lifting of the system constraint will lead to better performance the whole system (Barnard, 2013). And the application of the theory of constraints contributes to increasing the competitiveness of industrial companies, and adds value to customers and stakeholders (Watson, Blackstone \& Gardiner, 2007). And also reducing inventory costs, which reduces operating expenses and improves net income, and helps in producing a competitive advantage through obtaining best products, lower prices and faster response to customer needs (Hansan \& Mowen, 2006).

The theory of constraints constitutes an integrated framework that serves the various fields of the company's work, through the methodology it provides that is based on controlling and organizing all production stages within the company according to a specific time schedule, in order to be able to build a work environment free of errors and obstacles, that helps improve the company's profitability, and provide Information for management about the profitability achieved from the production activity and the possibility of its development (Al-Azeel, 2015). The theory of constraints is a management methodology or philosophy that aims to achieve operational effectiveness, in order to maximize the overall profitability of the facility, by achieving the effective use of its resources, and continuing to improve its performance through the process of continuous improvement (Bergawi, 2018). There are many benefits to using the theory of constraints (Marton \& Paulova, 2010):

- The possibility of an increase in productivity with minimal changes in operational processes. - A powerful and cost-effective tool to increase production capacity.

- Great for promoting teamwork, as the various work areas of the organization have an awareness of constraints, and the need to work together to help in the process of removing those constraints. 
MANAGEMENT SCIENCES

Vol. 11, No. 3, 2021, E-ISSN: 2225-8329 @ 2021 HRMARS

- A great process to support improvement efforts, as it provides immediate and tangible benefits.

- It allows capital and productivity growth without the need for additional time or additional employees.

- It provides a means of correct assessment of changes in business environment, and is used to select the best options that lead to correct behavior and decisions.

In the opinion of the researcher, the theory of constraints is a management method used by the company to manage any constraints that obstruct the company's operations, with the aim of controlling, treating and removing restrictions, to improve productivity, reduce costs, increase the operating income of the company, and create a competitive advantage for it.

\section{Competitive Advantage}

The competitive advantage is an important factor in the success of the company (Skinner, 2007). it's represent in the company's ability to use a new and unique vision, which enables it to stand against its competitors for long periods, and it helps to increase the company's flexibility to adapt to environmental and technological changes, in a way that ensures its growth, survival and continuity in the markets (Juma, 2018). Also, competitive advantage is defined as the company's ability to outperform competitors by following a specific strategy for competition (Selim,2013). Competitive advantage is the creation of better value for customers for the same or less cost than competitors, and the value to the customer is the difference between what the customer obtains from the benefit and what the customer sacrifices (Hansan \& Mowen, 2006).

Hasan (2017), he defined the competitive advantage as the company's ability to meet the desires and needs of customers; With the aim of maintaining the stability of the company, increasing its market share and maximizing profitability. It's also defined as the company's ability to do something better than its competitors, and give it a competitive advantage over them in the market, and this means the company's ability to produce and provide products to customers in a distinct way as offered by competitors (Al-Taweel \& Ismail, 2008).

In the opinion of the researcher, the competitive advantage is the company's ability to succeed, continue and survive, through its focus on several dimensions, with the aim of reducing cost, improving its operations and performance, improving the quality of services it provides, and responding quickly to customer requirements, according to their desires and on time. 
MANAGEMENT SCIENCES

Vol. 11 , No. 3, 2021, E-ISSN: 2225-8329 @ 2021 HRMARS

Dimensions of Competitive Advantage

Competitive advantage has five dimensions, according to the following table:

Table (1): Dimensions of competitive advantage

\begin{tabular}{|r|r|r|r|}
\hline Cost dimension & $\begin{array}{r}\text { The company's ability to remove bottlenecks and focus on } \\
\text { continuous improvement techniques, reduce waste in the use of } \\
\text { resources and other practices that contribute to reducing cost } \\
\text { and improving profitability (Modi \& Mishra,2011). }\end{array}$ \\
\hline Quality dimension & $\begin{array}{r}\text { The company's ability to produce products with specific } \\
\text { specifications that conform to the specifications requested by } \\
\text { customers, to reach the highest level of customer satisfaction, } \\
\text { improve the company's performance and maintain its survival in } \\
\text { the competitive markets (Rashid, Samir, \& Al-Taher,2015). }\end{array}$ \\
\hline Delivery Flexibility & $\begin{array}{r}\text { The company's ability to respond quickly and effectively to } \\
\text { uncertainties, instability and various environmental changes, } \\
\text { whether proactively or reactively (Yousuf, et al., 2019). }\end{array}$ \\
\hline The dimension of & $\begin{array}{r}\text { The company's ability to innovate and develop products and } \\
\text { production methods; to gain customer satisfaction and trust, } \\
\text { creativity }\end{array}$ \\
\hline Time dimension & $\begin{array}{r}\text { The company's ability to deliver orders to customers on time, or } \\
\text { faster than competitors (Chavez, et al. 2015). }\end{array}$ \\
\hline
\end{tabular}

\section{Study Methodology}

The study used the descriptive analytical approach, with the aim of describing the study variables, and analyzing the data collected from the sample members. The study population consisted of employees in the industrial companies in Al Mafraq Industrial Estate (MIE), it Lunched in 2016, (MIE) located within the King Hussein Bin Talal Development Area (KHBTDA) in AL Mafraq, which numbered (9) companies divided In different industrial sectors (plastic industries, oils and engines industry, fertilizers industry, chemical industries, food and agricultural industries), the study sample consisted of (managers, engineers, accountants, supervisors, and technicians) working in industrial companies located in the industrial city of Mafraq, their number (60) employees. The researcher prepared a questionnaire to achieve the objectives of the study, with the aim of measuring (the effect of applying the theory of constraints on the competitive advantage in Jordanian industrial companies), and (60) questionnaires were distributed, the number of retrieved and valid for analysis was (50), and the following is the distribution of the sample members: 
INTERNATIONAL JOURNAL OF ACADEMIC RESEARCH IN ACCOUNTING, FINANCE AND

MANAGEMENT SCIENCES

Vol. 11, No. 3, 2021, E-ISSN: 2225-8329 @ 2021 HRMARS

Table (2): Demographic distribution of the study sample

\begin{tabular}{|c|c|c|}
\hline Variable & Repetition & Percentage \% \\
\hline \multicolumn{3}{|c|}{ Academic Qualification } \\
\hline High School & 1 & 2 \\
\hline Master & 3 & 6 \\
\hline Bachelor & 25 & 50 \\
\hline Diploma & 14 & 28 \\
\hline \multicolumn{3}{|c|}{ Educational specialization } \\
\hline Accounting & 13 & 26 \\
\hline Business management & 7 & 14 \\
\hline Economics & 5 & 10 \\
\hline Other & 25 & 50 \\
\hline \multicolumn{3}{|c|}{ position } \\
\hline Manager & 4 & 8 \\
\hline Engineer & 11 & 22 \\
\hline Supervisor & 7 & 14 \\
\hline Accountant & 13 & 26 \\
\hline Technicians & 15 & 30 \\
\hline \multicolumn{3}{|c|}{ Years of experience } \\
\hline Less than 5 years & 15 & 30 \\
\hline 5 years - less than 10 years & 17 & 34 \\
\hline 10 years - less than 15 years & 12 & 24 \\
\hline Over 15 years & 6 & 12 \\
\hline
\end{tabular}

\section{Reliability Testing}

Before testing the hypothesis of the study, we will examine the reliability of all statements of questionnaire and its suitability for measuring the study variables. The alpha values of all statements for the independent variable (Applying the theory of constraints) were (0.726), and for the dependent variable (competitive advantage) were (0.809), and the overall reliability has been (0.824). Hence, it can be said that all the questionnaire statements were reliable, and therefore they were suitable for hypothesis testing. Table (3) highlights the reliability of all statements of variables:

Table (3): Reliability testing

\begin{tabular}{|l|c|}
\hline \multicolumn{1}{|c|}{ Variable } & Cronbach alpha \\
\hline Applying the theory of constraints & 0.726 \\
\hline competitive advantage & 0.809 \\
\hline Overall Reliability & 0.824 \\
\hline
\end{tabular}

\section{Hypothesis Testing}

The study has one main hypothesis, and it tested with the application of simple linear regression.

H01: There is no statistically significant impact of applying the theory of constraints on the competitive advantage. 
MANAGEMENT SCIENCES

Vol. 11, No. 3, 2021, E-ISSN: 2225-8329 ๔ 2021 HRMARS

Table (4): Regression( applying the theory of constraints \& competitive advantage)

\begin{tabular}{|c|c|c|c|c|c|c|}
\hline \multicolumn{7}{|c|}{ Model-1 } \\
\hline$R$ & $R^{2}$ & $\begin{array}{c}\text { Adjusted } \\
\mathrm{R}^{2}\end{array}$ & $\begin{array}{c}\text { Standard } \\
\text { Error }\end{array}$ & Df & $\mathrm{F}$ & Sig. \\
\hline 0.474 & 0.224 & 0.208 & 0.28297 & 1 & 13.887 & 0.001 \\
\hline
\end{tabular}

In this study Simple linear regression was used, to examine the relationship between the applying the theory of constraints and competitive advantage, the table (4) showed the coefficient of correlation was (0.474), this indicates a medium degree of correlation between the applying the theory of constraints and competitive advantage, and the level of significance (sig. $=0.001$ ) which is less than $(5 \%)$, and this confirms the significance of the regression.

Table (5): Beta Coefficients

\begin{tabular}{|c|c|c|c|c|c|}
\hline \multirow[t]{2}{*}{ Model } & \multicolumn{2}{|c|}{$\begin{array}{c}\text { unstandardized } \\
\text { Coefficients }\end{array}$} & $\begin{array}{c}\text { Standardized } \\
\text { Coefficients }\end{array}$ & \multirow[t]{2}{*}{$\mathrm{T}$} & \multirow[t]{2}{*}{ Sig. } \\
\hline & B & Std. Error & Beta & & \\
\hline (Constant) & 2.467 & 0.474 & & 5.199 & 0.000 \\
\hline $\begin{array}{l}\text { theory of } \\
\text { constraint }\end{array}$ & 0.415 & 0.111 & 0.474 & 3.727 & 0.001 \\
\hline
\end{tabular}

In the table (5) the unstandardized beta value showed impact of the applying the theory of constraints on competitive advantage, and beta coefficient was (0.474), with the level of significance (Sig.= 0.001 ), and this confirms the significance of the coefficients.

Based on the above, the null hypothesis is rejected, because the $(P<0.05)$, and it can be said: There is a statistically significant impact of applying the theory of constraints on the competitive advantage.

\section{Conclusion}

This study aimed to investigate the impact of applying the theory of constraints on the competitive advantage, the study reached the following result:

There is a statistically significant impact of applying the theory of constraints on the competitive advantage for industrial companies in Jordan, this indicates that industrial companies in Jordan are adopting ways to optimally exploit any constraints or bottlenecks, to increase the speed of response to customers' needs, and to respond quickly for any changes, whether in the company's internal environment or the external environment, to improve the quality of products, reduce production costs, increase companies' profitability, and to expand the base its customers, to enhance its competitive advantage.

\section{Recommendations}

The study recommended it is necessary for industrial companies to constantly search for the best ways and methods that help reduce constraints, reduce waste of resources, and continuous improvement in production processes, in order to maintain their competitive advantage. The study also recommended studying the impact of applying the theory of constraints on other variables or in other environments.

\section{The Study Contribution}

This study has theoretically contributed to offers a theoretical Framework for the theory of constraints, and the importance to applying it on industrial companies, and also offers a 
MANAGEMENT SCIENCES

Vol. 11, No. 3, 2021, E-ISSN: 2225-8329 @ 2021 HRMARS

theoretical Framework for competitive advantage, and its dimensions. Furthermore, the study offers a Theoretical Framework to extending the understanding of the impact of applying the theory of constraints on the competitive advantage for industrial companies in Jordanian environment, and the result of the study is classified as positive and reliable, and it will be relied upon in the future by researchers and management of industrial companies.

\section{References}

Al-Azeel, M. A. (2015). The integration between the theory of constraints (TOC) and the activity- based costing system $(A B C)$ and its impact on the profitability of productive departments - a case study, University of Aleppo, Aleppo, Syria.

Al-Maadidi, M. S., \& Al-Hadidi, H. O. (2008). The integration of activity based Costing with the theory of constraints and its role to enhance profitability. Journal of Baghdad College of Economic sciences University, (18), 177-206.

Al-Taweel, A. A., \& Ismail, R. I. (2009). The relationship between types of technical creativity and the dimensions of competitive advantage: a field study in a selected group of industrial companies in the province of Nineveh. The third scientific conference, under the slogan of "Business Administration Management: Contemporary Challenges". Jordan, Private Applied Science University, College of Economics and Administrative Sciences, Amman, Jordan.

Al-Zahra, B. F., Laila, H., \& Sarah S. (2017). The Role of Technological Innovation in Developing the Competitive Advantage of Small and Medium Enterprises - A Case Study of a Group of Small and Medium Enterprises in Algeria, Annaba Province. Journal of Research and Business Studies, 1(2), 142-154.

Al-Zamili, A. H. H. (2014). Importance of Constraints Theory in Improvement Effectiveness of Optimal Mixture for Productions. Al-Qadisiyah Journal For Administrative and Economic sciences, 15, (4), 200-213.

Atkinson, A. A., Kaplan, R. S., Matsumura, E. M., \&Young, S. M. (2012).Management accounting information for decision making and strategy execution, $\left(6^{\text {th }} e d\right)$.Upper Saddle River, New Jersey, NJ:Pearson Education Inc.

Balakrishnan, J., Cheng, C. H., \& Trietsch, D. (2008). The Theory of Constraints in academia: its evolution, influence, controversies, and lessons. Operations Management Education Review, 2,97-114.

Barnard, A. (2013) .What is theory of constraints (toc)? .Retrieved from https://dralanbarnard.com/pdf/What_is_Theory_of_Constraints_(TOC).PDF

Bergawi, A. (2014). The impact of integration relationship between the system of Total quality management and Theory of Constraints on reducing cost and improving achievement (A field study). Tishreen University Journal for Research and Scientific Studies Economic and Legal Sciences Series, 36, (4).

Chavez, R., Yu, W., Gimenez, C., Fynes, B., \& Wiengarten, F. (2015). Customer integration and operational performance: The mediating role of information quality. Decision Support Systems, 80, 83-95. doi: 10.1016/j.dss.2015.10.001

Da Silveira, G. J. C. (2005).Improving trade-offs in manufacturing: Method and illustration. International Journal of Production Economics, 95 ,(1),27-38.

Goldratt, E. M., \& Cox, J. (2004). The goal. A process of ongoing improvement, $\left(3^{\text {th }}\right.$ ed.). North River press .Retrieved from https://pdfroom.com/books/thegoal-a- process-of-ongoing-improvement-third-revised-edition-20thanniversary- edition/Wx5aDyOD2BJ 
MANAGEMENT SCIENCES

Vol. 11, No. 3, 2021, E-ISSN: 2225-8329 ๔ 2021 HRMARS

Hansen, D. R., \& Mowen, M. M. (2006).Cost management -Accounting and control, $\left(5^{\text {th }}\right.$ ed), Thomson South-Western:Rob Dewey Inc.

Hasan, A. I. S. (2017). The impact of total quality management practices on achieving competitive advantage : a field study in Jordanian pharmaceutical companies according to firms' size. (Unpublished Master's Thesis), Middle East University, Amman, Jordan.

Horngren, C. T., Dater, S. M., \& Rajan, M. V. (2012).Cost accounting a managerial emphasis, $\left(14^{\text {th }}\right.$ ed).Upper Saddle River, New Jersey,NJ:Prentice Hall International Inc.

Inman, R. A., Sale, M. L., \& Green, K. W. (2009).Analysis of the relationships among TOC use, TOC outcomes, and organizational performance. International Journal of Operations and Production Management, 29,(4), 341-356.

Liu, X., Shen, L., \& Zhang, K. (2021).Estimating the Probability Distribution of Construction Project Completion Times Based on Drum-Buffer-Rope Theory. Applied Science, 11(15), 7150. doi.org/ 10.3390/app11157150

Marton, M., \& Paulova, I. (2010) Applying the theory of constraints in the course of process improvement. Slovak university of technology in Bratislava,18(29), 71 76.doi.org/10.2478/v10186-010-0028-9

Modi, S. B., \& Mishra, S. (2011). What drives financial performance-resource efficiency or resource slack?. Journal of Operations Management, 29(3), 254-273. doi:10.1016/j.jom.2011.01.002

Juma, M. A. (2018). The Impact of Excellence in Competitive Advantage in Private Colleges. Journal of AlMaarif University College, (26), 13-50.

Orue, A., Lizarralde, A., Amorrortu, I., \& Apaolaza, U. (2021). Theory of Constraints Case Study in the Make-to-Order Environment. Journal of Industrial Engineering and Management, 14(1), 72-85. doi.org/10.3926/jiem.3283

Rashid, S., Samir, B., \& Al-Taher, D. (2015). Total Quality Management as an Entrance to Achieving Competitive Advantage in Business Organizations. The Journal of Economic and Financial Studies, 8(2), 126-140.

Selim, I. M. (2013). The role of creativity in improving the competitive advantage of small and medium enterprises. (Unpublished Master's Thesis), Kasdi Merbah University, Ouargla, Tunisia.

Skinner, W. (2007).Manufacturing strategy: the story of its evolution. Journal of Operations Management, 25 (2),328-335.

Simsit, Z. T., Gunay, N. S., \& Vayvay, O. (2014). Theory of Constraints: a literature review. Procedia-Social and Behavioral Sciences, 150, 930-936.

Tsou, C. (2013). On the strategy of supply chain collaboration based on dynamic inventory target level management: a theory of constraint perspective. Applied Mathematical Modelling, 37 ( 7),5204-5214.

Watson, K. J., Blackstone, J. H., \& Gardiner, S. C. (2007). The evolution of a management philosophy: the Theory of Constraints. Journal of Operations Management, 25,( 2), 387- 402.

Yosuf, A., Haddad, H., Miklos, P., Kozlovskyi, S., Mohylova, A., Shlapak, O., \& Felfoldi, J. (2019). The effect of operational flexibility on performance: A field study on small and medium-sized Industrial Companies in Jordan. Montenegrin Journal of Economics,15(1),47-60. DOI: $\quad$ 10.14254/1800-5845/2019.15-1.4 